УДК 364-78:331.54-053.81 (045)

DOI:

Антон Кравченко, аспірант кафедри сочіальної роботи, інженер з охорони праці Комунального закладу “Харківська гуманітарно-педагогічна академія”

Харківської обласної ради

\title{
ВПЛИВ ГЕНДЕРНИХ СТЕРЕОТИПІВ НА ВИБІР МОЛОДДЮ ПРОФЕСІЇ ТА КОНКУРЕНТОСПРОМОЖНІСТЬ НА РИНКУ ПРАЦІ
}

У статті розкриваються і аналізуються сучасні гендерні стереотипи, що акумулюються у суспільстві та нав'язуються молоді у проиесі обрання майбутньої професії.

Визначено сутність терміна гендерні стереотипи як стійких для даного суспільства в конкретний історичний період уявлень про відмінність між чоловіком і жінкою, про їх місце і роль у сім 'ї, на ринку праці й у иілому у суспільстві. Розглянуті умовні групи гендерних стереотипів (уявлення про психологічні риси та якості чоловіків і жінок; закріплення професійних ролей чоловіків і жінок; сегрегація ринку праці тобто поділ прачі на жіночу та чоловічу).

Ключові слова: гендерні стереотипи; студентська молодь; професіоналізація; конкурентоспроможність; ринок праці; кар'єрний радник; гендерна сегрегація.

Табл. 2. Літ. 9.

Anton Kravchenko, Postgraduate Student of the Social Work Department, Civil Protection Engineer, Kharkiv Humanitarian and Pedagogical academy,

Kharkiv Regional Council

\section{INFLUENCE OF GENDER STEREOTYPES ON CHOICE OF YOUNG PEOPLE'S PROFESSION AND COMPETITIVENESS IN THE LABOUR MARKET}

This article reveals and analyzes modern gender stereotypes, which accumulate in society and affect the young people in the process of choosing their future profession.

The article highlights the essence of the term gender stereotypes - stable for a given society in a particular historical period of the perception of the distinction between a man and a woman, their place and role in the family, the labor market and the whole society. The author identified the main groups of gender stereotypes (the notion of psychological risi ties and qualities of men and women; consolidation of professional roles of men and women; segregation of the labor market that is the division of labor for women and men).

The main mechanisms and consequences of the impact of gender stereotypes on the professional choice of young people have been identified, and the ways to improve them at the state level have been characterized. Official statistics on gender distribution of types of professional activity, the level of women's and men's stats, and the level of their involvement in reproductive work were analyzed. The presence of gender imbalance in the professional sphere and gender stereotypes are considered as a factor reducing the competitiveness of women in the labor market.

Using the data from the analysis of the accession company 2020-2021 years for 10 specialties: Education; Art and Humanities; Social Sciences, Journalism and Information; Health and Social Work; Business, Administration and Law; Natural Sciences, Mathematics and Statistics; Services; Agrarian Sciences; Engineering, Manufacturing and Civil Engineering; Information technology, we can certify that the analysis of educational priorities of female applicants for STEM specialties, showed a high level of motivation to obtain a profession in this field, While the applicants for education, arts and humanities, social sciences, journalism and information have a low priority (lower than $3 \mathrm{rd}$ ).

It is announced that the introduction of the position of a caring educator in secondary educational institutions and increased training of such professionals within the specialty "Social Work" in the WVO on the basis of a nondiscriminatory approach in education will allow students to make an informed choice of their profession, correctly assess their own abilities and capabilities, identify their interests, and help them figure out the role models in professions stereotypically considered as "male" or "female".

Keywords: gender stereotypes; student youth; professionalization; competitiveness; labor market; caring peer; gender segregation.

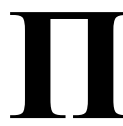

остановка проблеми у загальному вигляді та її зв'язок із важливими науковими чи практичними завданнями. На сьогоднішній день гендерні стереотипи займають значне місце в сфері людської життєдіяльності. Починаючи з моменту народження на дитину навішуються соціальні ярлики залежно від статі з психологічними та 


\section{ВПЛИВ ГЕНДЕРНИХ СТЕРЕОТИПІВ НА ВИБІР МОЛОДДЮ ПРОФЕСІЇ ТА КОНКУРЕНТОСПРОМОЖНІСТЬ НА РИНКУ ПРАЦІ}

фізіологічними особливостями. В умовах сучасних змін суспільства відбувається тенденція трансформації цих стереотипів, перегляду їх значення у процесі соціалізації молоді, зокрема під час вибору професії та оволодіння нею. Відповідно, головною тенденцією професіоналізації молоді стає орієнтування на індивідуальність людини, iі1 вибір та шляхи самореалізації поза статевою приналежністю. На жаль, сьогодні застарілі гендерні стереотипи, які заважають цілісно розвиватися особистості, все ж залишаються доволі стійким негативним чинником професіоналізації, що часто зумовлює помилковий професійний вибір, зменшує можливості молодої людини щодо самореалізації у професійній сфері, знижує рівень конкурентоспроможності фахівців і фахівчинь на ринку праці. Насамперед це пояснюється недостатнім рівнем обгрунтованості самої концепції гендерного й недискримінаційного підходів до професіоналізації молоді, а також недостатньою розробленістю механізмів опору стереотипним поглядам на гендерний розподіл професій у суспільстві, відсутністю у системі освіти фахівців, які змогли б спрямовувати активність молоді у напрямі вільного професійного вибору.

Аналіз основних досліджень і публікацій. У наукових дослідженнях актуальним є питання гендерних стереотипів у різних інституціях та сферах людської діяльності: як інструментальної основи маніпулювання в сімейному судочинстві України: соціологічний аспект (О. Пархоменко, 2019); населення України при прийнятті електоральних рішень (Н. Дзюба, 2018); як чинник соціалізації студентів гуманітарних спеціальностей П. Скляр та Д. Мамаєв, 2014); представлення жінок і чоловіків на ринку праці (Б. Магдюк, 2011); їх вплив на професійну діяльність в Україні (Т. Медіна, $2015)$; у сучасному українському суспільстві (Т. Єрмолаєва, 2017); як соціальна проблема сучасних жінок (К. Борщ та М. Ляшко, 2017); та вибір професії (О. Дніпрова, 2018); в медіапросторі як фактор впливу на соціалізацію учнівської молоді (М. Андреєва, О. Василенко та К. Дмитренко, 2021).

Серед міжнародних дослідників гендерних стереотипів можемо відзначити: P. Campbell (гендерна рівність вчителів та гендерні відмінності між дівчатами і хлопцями); M. Favara (вплив гендерних стереотипів на професійний вибір учнів); A. Ifegbesan (гендерно-стереотипні переконання та сприйняття вчителів загальноосвітніх шкіл), M. Sadker (диференційоване ставлення до дівчат і хлопців у школі та до яких наслідків це призводить), J. Tiedemann (гендерні стереотипі та математичні здібності), M. White (імпліцитні та явні професійні гендерні стереотипи).

Аналізуючи їхні праці, можемо зробити висновок, що, незважаючи на досить значну кількість наукових наробок, в яких досліджуються різні аспекти впливу гендерних стереотипів на життя та діяльність людини, дослідницями та дослідниками не визначені і не охарактеризовані специфічні впливи гендерних стереотипів на професіоналізацію молоді. У зв'язку з цим видається актуальним теоретичне осмислення й емпіричне вивчення питання впливу гендерних стереотипів на вибір молоддю професії та конкурентоспроможність молодих людей на ринку праці.

Метою статті $€$ аналіз впливу гендерних стереотипів на професіоналізацію молоді та обгрунтування можливостей подолання стереотипів гендерної сегрегації у професійній cферi.

Виклад основного матеріалу. Гендерні стереотипи - це стійкі у межах певного суспільства в конкретний історичний період соціальні і персональні уявлення про відмінність між чоловіком і жінкою, про їх місце і роль у сім’ї, на ринку праці й безпосередньо у суспільстві [7]. У навчально-методичному посібнику “Гендерночутливий підхід у роботі з вразливими верствами населення у соціально-правовій сфері” акцентовано увагу на умовному поділі гендерних стереотипів:

- на уявленнях про психологічні риси та якості чоловіків у жінок (згідно з цими стереотипами чоловікам притаманне логічне мислення, здатність приймати рішення, жінки ж навпаки, не здатні використовувати логічне мислення, більш емоційні);

- закріплення професійних ролей чоловіків та жінок (“Місце жінки на кухні та поряд 3 дітьми", а чоловік має заробляти гроші);

- сегрегація ринку праці тобто поділ праці на жіночу та чоловічу (під жіночою мають на увазі обслуговуючу і виконавчу працю, під чоловічою - інструментальну, творчу) [1].

Таким чином, у суспільстві сформовані стереотипи та гендерні ролі чоловіка і жінки. Механізми соціального конструювання гендерних стереотипів простежуються у всіх сферах взаємовідносин між людьми. Найпотужнішим є мова, бо вона “віддзеркалює” різне ставлення суспільства до жінок і чоловіків, тому є одним із джерел відтворення гендерних ролей.

Українська держава зробила вагомий внесок у закріплення фемінітивів (слів жіночого роду, які 


\section{ВПЛИВ ГЕНДЕРНИХ СТЕРЕОТИПІВ НА ВИБІР МОЛОДДЮ ПРОФЕСІЇ ТА КОНКУРЕНТОСПРОМОЖНІСТЬ НА РИНКУ ПРАЦІ}

є альтернативними до аналогічних “чоловічих" назв) прийнявши 30 травня 2019 р. нову версію правопису, норми та правила, якого рекомендовано застосовувати в усіх сферах суспільного життя. Міністерство розвитку економіки, торгівлі та сільського господарства України наказом № 1574 від 18.08.2020 р. "Про затвердження зміни № 9 до національного класифікатора ДК 003:2010" офіційно дозволило фемінітиви для посад працівниць, утворених за правилами чинного правопису, у кадровій документації, тобто трудових книжках, наказах, кадровому i загальному діловодстві, кореспонденції та всіх інших галузях праці, де застосовується класифікатор професій).

Дуже потужним $\epsilon$ механізм репрезентування гендерних стереотипів в освіті. Починаючи 3

Міністерства охорони здоров'я України від 29 грудня 1993 р. № 256” скасувало розподіл професій, відкривши доступ жінкам до 450 раніше заборонених професій, які пов'язаними із підвищеним професійним ризиком та традиційно вважалися “чоловічими".

Розглянемо 3 точки зору гендерного конструювання професійного середовища результати вступної компанії 2020-2021 рр. на теренах України. Аналіз 2020 р. було здійснено аналітичним центром Cedos у рамках Ініціативи 3 розвитку аналітичних центрів в Україні, яку виконує Міжнародний фонд “Відродження" у партнерстві з Ініціативою відкритого суспільства для Європи (OSIFE) за фінансової підтримки Посольства Швеції в Україні [2]. Дані наведені у відсотках табл. 1.

Таблиця 1.

Аналіз вступної компанії 2020 р.

\begin{tabular}{|c|c|c|c|}
\hline № & Спеціальність & Жінки \% & Чоловіки \% \\
\hline 1 & Освіта & 76,86 & 23,14 \\
\hline 2 & Мистецтво та гуманітарні науки & 76,30 & 23,70 \\
\hline 3 & Соціальні науки, журналістика та інформація & 70,03 & 29,97 \\
\hline 4 & Охорона здоров'я та соціальна робота & 61,53 & 38,47 \\
\hline 5 & Бізнес, адміністрування та право & 60,98 & 39,02 \\
\hline 6 & Природничі науки, математика та статистика & 51,21 & 48,79 \\
\hline 7 & Сфера обслуговування & 44,36 & 55,64 \\
\hline 8 & Аграрні науки & 37,08 & 62,92 \\
\hline 9 & Інженерія, виробництво та будівництво & 28,64 & 71,36 \\
\hline 10 & Інформаційні технології & 18,48 & 81,52 \\
\hline
\end{tabular}

дитячого садка, де відбувається поділ іграшок на дівчачі та хлопчачі, книжок, що ілюструють певні моделі поведінки, які мають бути притаманні дитині певної статі. Формування продовжується у школі, де й досі залишається поділ дівчат та хлопців на уроках праці, де дитина не має можливості обрати те, що іiі цікавить, а має вивчати суто “жіночі” або “чоловічі” види праці. Вища школа, на жаль, так само є місцем де репрезентація продовжується. Більшість абітурієнтів у виборі майбутньої професії орієнтуються на “жіночі" та “чоловічі" спеціальності, хоча Міністерство охорони здоров’я України своїм наказом № 1254 від 13 жовтня 2017 р. "Про визнання таким, що втратив чинність, наказу
Аналіз вступної компанії 2021 р. було здійснено за допомогою освітнього порталу Вступ.Освіта.иа у Харківській області [4] таблиці 2.

Аналізуючи результати вступних компаній 2020-2021 pp., можемо відзначити, що, незважаючи на прийняття в Україні низки документів щодо встановлення гендерної рівності у професійній сфері, гендерний дисбаланс щодо галузей професіоналізації молоді досі існує. Розглядаючи причини такого дисбалансу, відзначимо, що на вибір майбутньої професії на абітурієнтів та абітурієнток, безумовно, впливають сформовані в суспільстві стереотипи поділу професій на “жіночі” та “чоловічі”, хоча, аналізуючи таблиці, відзначимо, що на 
Таблиця 2.

Аналіз вступної компанії у Харківській області 2021 р.

\begin{tabular}{|l|l|l|l|}
\hline № & Спеціальність & Жінки \% & Чоловіки \% \\
\hline 1 & Освіта & 75,63 & 24,37 \\
\hline 2 & Мистецтво та гуманітарні науки & 79,07 & 20,93 \\
\hline 3 & Соціальні науки, журналістика та інформація & 69,09 & 30,91 \\
\hline 4 & Охорона здоров’я та соціальна робота & 68,33 & 40,92 \\
\hline 5 & Бізнес, адміністрування та право & 59,08 & 46,73 \\
\hline 6 & Природничі науки, математика та статистика & 53,27 & 51,46 \\
\hline 7 & Сфера обслуговування & 49,54 & 63,87 \\
\hline 8 & Аграрні науки & 36,13 & 53,19 \\
\hline 9 & Інженерія, виробництво та будівництво & 30,81 \\
\hline 10 & Інформаційні технології & 46,35 \\
\hline
\end{tabular}

спеціальності сфери обслуговування у 2021 р. у Харківській області гендерного дисбалансу не виявлено: жінки 49,54 \% та чоловіки 51,46\%, також зрушення у бік рівності відбулося на спеціальності інформаційні технології 46,35 \% та 53,65 \%.

Аналіз освітніх пріоритетів абітурієнток до навчання на STEM спеціальності, показує високий ступінь їх вмотивованості щодо отримання професії цього напряму, в той час як абітурієнти на спеціальності освіта, мистецтво та гуманітарні науки, соціальні науки, журналістика та інформація ставлять невисокий пріоритет (нижче 3-го) [3].

Проаналізувавши вступнукомпанію 2020-2021 pp., можемо стверджувати, що гендерна сегрегація все таки існує, тому розглянемо умови, які б сприяли подоланню цього явища. Насамперед це створення сприятливих умов у закладах освіти, через педагогічну комунікацію (використання фемінітивів, невикористання гендерних стереотипів та сегрегаційних життєвих уявлень); зміна змісту освітнього контенту (розробка уроків, виховних та позашкільних заходів 3 урахуваннямнедискримінаційного тагендерночугливого підходів); гендерна просвіта адміністрації школи, вчителів і вчительок, зокрема навчання використовувати у своїй роботи елементи недискримінаційного та гендерночутливого підходів; запровадження посади кар'єрного радника у закладах загальної середньої освіти дозволить учням та ученицям зробити усвідомлений вибір професії, оцінити власні здібності, виявити свої інтереси, ознайомить 3 рольовими моделями в професіях, які стереотипно вважаються “чоловічими” або “жіночими”, і це значно зменшить прояви гендерної сегрегації на ринку праці; здійснення постійної інформаційнопропагандистської діяльності щодо ліквідації всіх форм дискримінації за ознакою статі та вжиття заходів, спрямованих на формування гендерної культури населення [5]; створення на базі закладів вищої освіти гендерних центрів, діяльність яких спрямовувалася б на посилення гендерного аспекту в змісті соціально-гуманітарних дисциплін, активізацію виховних заходів, організацію науково-дослідницької роботи з метою свідомого забезпечення засобами освіти рівних прав та можливостей жінок і чоловіків, ліквідації всіх форм дискримінації, запобігання насильству в усіх сферах життя суспільства, протидії торгівлі людьми тощо [6].

Висновки і перспективи подальших досліджень. Отже, незважаючи, на те що у 2017 р. Україна відкрила доступ жінкам до 450 раніше заборонених професій (ливарні роботи, професії чорної і кольорової металургії, професії електротехнічного виробництва, тютюновомахоркового і ферментаційного виробництва, цивільної та військової оборони тощо), застарілі гендерні стереотипи, заважають цілісно розвиватися особистості та впливають на професійну орієнтацію старшокласників і старшокласниць, що зумовлює помилковий професійний вибір та зменшує можливості молодої людини щодо самореалізації у професійній 


\section{ВПЛИВ ГЕНДЕРНИХ СТЕРЕОТИПІВ НА ВИБІР МОЛОДЛЮ ПРОФЕСЇ ТА КОНКУРЕНТОСПРОМОЖНІСТЬНА РИНКУ ПРАЦІ}

сфері. Насамперед, це пояснюється недостатнім рівнем обізнаності вчителів і вчительок, батьків щодо рівного ставлення до дівчат і хлопців в освітньому процесі (зокрема щодо очікувань до старанності та успішності дівчат та хлопців), а також недостатньою розробленістю механізмів запровадження гендерного підходу у роботу сучасних закладів освіти.

\section{ЛІТЕРАТУРА}

1. Анголенко В.В. та ін. Гендерночутливий підхід у роботі з вразливими верствами населення у соціально-правовій сфері: навч.-метод. посіб. / за заг. ред. О.І. Рассказової. Хаків, КЗ "ХГПА" XOP, 2017. $78 \mathrm{c}$.

2. Жерьобкіна Т., Куделя М., Слободян О. Вибір вищої освіти: гендерний аналіз. URL: https:/ /www.irf.ua/wp-content/uploads/2021/01/zvit gendernyj vstup na sajt 1.pdf (дата звернення: 26.09.2021).

3. The Global Gender Gap Report 2021. URL: https:/gtmarket.ru/ratings/global-gender-gap-index (дата звернення: 26.09.2021).

4. Освітній портал Вступ. Освіта.ua. URL: https://vstup.osvita.ua/r21/ (дата звернення: 26.09.2021).

5. Про забезпечення рівних прав та можливостей для жінок і чоловіків: Закон України від 8 верес. 2005 р. №2866-IV. Офіиійний портал Верховної Ради України. URL:(дата звернення: 26.09.2021).

6. Рассказова О., Онипченко О., Чернецька Ю. Діяльність осередків гендерної освіти ВНЗ як умова імплементації гендерного компонента в освіту: досвід роботи ЦГО ХГПА. Гендерна парадигма освітнього простору, 2016, № 3. С. 165173.

7. Рассказова О. І., Григоренко В. Л. Гендерна соціальність особистості: структурний аналіз. Гендерна політика міст: історія і сучасність. Харків, 2015. С.229-230.

\section{REFERENCES}

1. Anholenko, V.V. etc. (2017). Hendernochutlyvyi pidkhid $u$ roboti $z$ vrazlyvymy verstvamy naselennia u sotsialno-pravovii sferi [Gender-sensitive approach in working with vulnerable groups in the social and legal sphere: training manual]. (Ed.). O.I. Rasskazova. Kharkiv, 78 p. [in Ukrainian].

2. Zherobkina, T., Kudelia, M. \& Slobodian, O. (2021). Vybir vyshchoi osvity: hendernyi analiz [Choice of higher education: gender analysis]. Available at: https://www.irf.ua/wp-content/uploads/ 2021/01/zvit_gendernyj_vstup_na_sajt_1.pdf (Accessed 26 Sept. 2021). [in Ukrainian].

3. The Global Gender Gap Report 2021. Available at: https://gtmarket.ru/ratings/global-gender-gap-index (Accessed 26 Sept. 2021). [in English].

4. Osvitnii portal Vstup.Osvita.ua [Educational portal Vstup.Osvita.ua]. Available at: https:// vstup.osvita.ua/r21/ (Accessed 26 Sept. 2021). [in Ukrainian].

5. Pro zabezpechennia rivnykh prav ta mozhlyvostei dlia zhinok i cholovikiv: Zakon Ukrainy vid 8 veres. 2005 r. №2866-IV [On ensuring equal rights and opportunities for women and men: Law of Ukraine of September 8. 2005 No 2866-IV.]. Official portal of the Verkhovna Rada of Ukraine. Available at: https://zakon.rada.gov.ua/laws/show/2866-15\#Text (Accessed 26 Sept. 2021)._[in Ukrainian].

6. Rasskazova, O., Onypchenko, O. \& Chernetska, Yu. (2016). Diialnist oseredkiv hendernoi osvity VNZ yak umova implementatsii hendernoho komponenta $\mathrm{v}$ osvitu: dosvid roboty TsHO KhHPA [Activities of gender education centers of higher education institutions as a condition for the implementation of the gender component in education: the experience of the Center for Gender Education of Municipal Establishment "Kharkiv HumanitarianPedagogical Academy"]. "Gender paradigm of educational space”, No. 3, pp. 165-173. [in Ukrainian].

7. Rasskazova, O. I. \& Hryhorenko, V. L. (2015). Genderna sotsialnist osobystosti: strukturnyi analiz [Gender personality of the individual: structural analysis]. "Gender policy of cities: history and modernity”. Kharkiv, pp. 229-230. [in Ukrainian].

Стаття надійшла до редакції 30.08.2021

\section{G58080ल2058080}

“Фва основні надбання людської природи - ие розум і міркування”.

Tisymapx

давньогрецький письменник

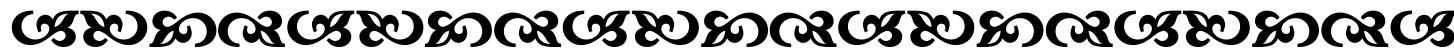

